\title{
Modernity and natalism in Russia: Historic perspectives
}

\author{
Nina Kouprianova
}

\begin{abstract}
Less than desirable indigenous birth rates in Western Europe have generated interest toward examining the question of natalism - an organised state initiative to manage and promote reproduction, child rearing, health, as well as related neotraditional cultural values - from a comparative perspective. This paper reviews the history of natalism in the USSR and contemporary Russia within the greater framework of modernity, by focusing on sweeping questions of ideology and geopolitics as well as current historic models. Economic stability is not an unimportant factor, yet it is authentic traditional culture that is of equal, if not greater, importance, even if expressed through state policies.
\end{abstract}

\section{JEL classification}

Z; J13; J11

\section{Keywords}

USSR; Russia; natalism; Modernity; demographics; neo-traditionalism 


\section{Introduction}

"I can't believe I wanted an abortion," states a rather blunt Soviet poster from 1961, depicting a woman looking fondly upon her newborn. ${ }^{1}$ Those with a popular knowledge of Russian history associate the natalist drive in the USSR with the iconic heroic-mother imagery in the era of Joseph Stalin. Yet natalism first appeared in 1920s Soviet Union and has not left since (perhaps, with certain exceptions in the 1990s-early 2000s). This was - and remains - an organised state initiative to manage and promote reproduction, child rearing, health, education, and socio-cultural mores, as they pertain to family relations at large, not just the fertility drive in the strict demographic sense of the word. The government's attempts to boost the population size in the USSR and the Russian Federation, respectively, appeared to coincide with modest to positive results, whether the Stalinist programme of overt propaganda and awards that were paralleled by a natural population increase after the Second World War or the contemporary Vladimir Putin era campaign that combines financial reward and cultural projects.

Historically, natalism is a product of modernity. Pre-modern governments in the West and Russia certainly maintained an interest in the people they governed in terms of taxation, military service, and territorial control, among others. But it was not until the post-Enlightenment period that the state sought to make its respective populations "legible" as scholar James Scott put it. It accomplished the latter by dividing its subjects into manageable segments, thereby monopolizing its ability to intervene, and demonstrating a progressively greater investment in its subjects' health, reproduction, education as the marriage between technical capabilities and social capital, and other formerly privately held categories within a particular ideological framework (in the 20th century, these were liberalism, communism, and fascism) (Scott 1998: 78). Today, many scholars do not question state involvement in these matters, per se, only their extent. By and large, criticism of the attempts to boost fertility comes from ecologists and those concerned with global population growth in relation to the planet's limited resources.

In terms of birth rates, specifically, modern states' most basic motivation thereof stemmed from the need to replenish those lost in war. There were also vital geopolitical concerns, i.e., maintaining a population large enough to defend a country's borders, especially applicable in the case of resource-rich USSR and its heir. Another relevant factor was the relationship between workforce size, social services, and taxation levels (hidden or otherwise) both in historically industrial socialist countries and in contemporary service- and consumption-oriented liberal democracies of the West. ${ }^{2}$

In this context, European welfare states may seem benign by comparison to their authoritarian counterparts, but their keen interest in the subject of birth rates, education, and other related matters in Europe-proper is guided by the same overarching principle of population "legibility." In the decades since the 1970s, the reasons for mass immigration into Europe have been economic, demographic, and postcolonial. $^{3}$ That is to say, its immediate purpose has been to ensure that an adequate number of taxpayers is available in order to maintain all the social programs along with other tax-funded projects, not to mention guaranteeing sufficient support for a Western European liberal democracy in its variants.

\footnotetext{
1 See poster selection "Materinstvo v illiustratsiiakh," Materinstvo.ru (consulted 10 March 2013): materinstvo.ru/art/6214/.

${ }^{2}$ In terms of ideology, it would be more accurate to use the term "post-liberal" after 1991, as I explain below. However, I cover large periods of time in this paper, hence the usage of "liberalism" to avoid confusion.

${ }^{3}$ Some argue that migration is primarily economically driven, but one cannot divorce the importance thereof from the Western European liberal democratic ideology per se.
} 
Supranational bureaucratic bodies like the United Nations regularly issue reports with thinly veiled threats about raising the retirement age to 75 , for instance, if certain migration levels are not maintained in order to support the current system. ${ }^{4}$

First, it is questionable as to whether the migrants can theoretically support the low indigenous birthrates, ultimately leading to systemic failure. Second, the new Europeans' relocation comes at a price for both the migrants and the hosts. Of course, the implicit (or, at times, explicit) population management technique here comprises a strong socio-cultural component, ensuring that the said newcomers adhere to the dominant secular liberal ideology - which, at times, is quite foreign to their own background - under the faulty assumption that cultures are interchangeable. On the other hand, they undermine the ethno-cultural cohesion of the dominant indigenous peoples. Considering the attention paid to the failures of this brand of multiculturalism in the European and American media in the recent years, it is unsurprising that there is an interest in somewhat alternative models like the Russian natalist variant. ${ }^{5}$

When it comes to natalism in the USSR, specifically, Western liberal historians generally place it in the context of "neo-traditionalism." They describe it as a phenomenon, in which modern secular states take over the role of authentic, spontaneously occurring tradition in pre-modern societies, realizing the sheer power of the latter as a mobilisation tactic. In this view, "neo-traditionalism" in the USSR ranged from the limited reintroduction of patriarchal gender roles to the usage of historic and folk heroes for agitational purposes (Martin 2000: 348-367). This framework is not inaccurate, and is quite practical. However, it emphasises the powerful state, while somewhat downplaying the vast support thereof among the masses. Of course, Western scholars of Russian history have rejected the original black and white "totalitarian" model of a near-omnipotent government and a submissive, oppressed population, but continue to debate the particular relationship between the state and its subjects.

In order to understand the longevity of natalist initiatives and their apparent successes (or lack thereof), we must examine their roots. Let us briefly review the facts both in the USSR and contemporary Russia. Each historical period will be accompanied by an analysis focused on ideology, as a partial imposition or borrowing of a foreign, i.e., Western European value system, as well as geopolitics, surpassing ideology. We will then discuss the benefits and drawbacks of current historic models and offer an alternative view that incorporates Russian folkic undercurrents in the era of modernity and postmodernity. In other words, the primary focus here is the history and theory of natalism in the USSR and Russia within a socio-cultural framework, not specific fertility behaviour, policies, and other heavily statistical information, although some applicable examples will be given.

\section{History of Natalism in the USSR}

The earliest Soviet posters advocating natalism appeared at the beginning of the 1920s immediately after the Revolutionary and Civil wars, when the new regime consolidated its military and political power just enough to focus on social and cultural issues affecting the new political entity. They pointed both to ideological concerns - the increased role in child rearing on the part of the state as one of the goals to create a new generation of productive Soviet citizens - along with practical replenishment of those who died in combat. While this concern found its

\footnotetext{
4 "New Report on Replacement Migration Issued by UN Population Division" (17 March 2000), United

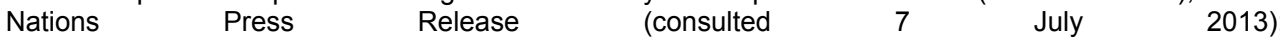
http://www.un.org/News/Press/docs/2000/20000317.dev2234.doc.html.

5 See, for instance, "Merkel says German multicultural society has failed," BBC (consulted 8 March 2013): http://www.bbc.co.uk/news/world-europe-11559451.
} 
greatest expression throughout the 20th century, it had even earlier roots within the modern Western liberal paradigm which undoubtedly affected pre-revolutionary Russia. This was the state's growing attention to the bodies of its subjects, which at the end of the 19th and the beginning of the 20th century pertained to questions of cleanliness, hygiene, and public health particularly in the case of the lower classes. Arguably, one of the better known initiatives in public memory was that of Jacob Riis, whose photographs of New York slums were used to garner interest in social reform (Riis 1890).

In the nineteenth century Russian Empire, the state's involvement in the matters of the body pertained by and large to the question of corporal punishment and military service. Otherwise, family matters were generally a private issue as compared to modern and contemporary macro- and micro-management; there was no unified system of school education, for instance. Large families were desirable for two reasons. First, much like elsewhere, having several children ensured that at least some of them survived into adulthood at a time when many detrimental healthrelated factors, such as epidemics, could strike populations. Second, the Russian Empire was generally a religious society, making the patriarchal family structure and large family size preferable. For religious adherents, regardless of denomination, there was a certain sense of shared responsibility to having children, which was not one of the state, but one of faith and cultural traditions.

In the last hundred years, if any generalisations could be made about the purpose of natalist policies in the USSR and Russia from the point of view of the state, then it is two-fold. First comes geopolitics in order to maintain a population large enough to defend the country's borders. Second comes social engineering within the general context of modernity in order to provide adequate workforce-taxpayer numbers among responsible patriotic citizenry.

When it comes to geopolitics, natalism served as a method for producing an adequate number of citizens to defend the territorial integrity of the USSR and the vast natural resources within - oil, gas, minerals, etc. In modern-day Russia, this issue is even more pressing if one were to consider the rising commodity prices. In light of the USSR's and contemporary Russia's uneven population distribution with high concentration in the European part of the continent, the state engaged in a number of development and relocation initiatives in Siberia and the Far East in order to reduce vulnerability in those areas (e.g., the creation of entire industrial cities in the Ural mountains, such as Magnitogorsk, in the Soviet period and economic and infrastructural projects in the contemporary Russian Far East, albeit lesser by comparison, like Rosneft's mining operations in Sakhalin). This frontier drive can be traced back to Russia's earliest expansion eastward and Yermak's conquest of Siberia in the late 1500s, not only as the means to access important trade routes, but also to control the newly acquired lands militarily and through the presence of a sufficiently sized subject population.

In the modern period, this vulnerability has manifested on numerous occasions from the British attempts to check Russia during the so-called Great Game in Central Asia and the Crimean wars in the late imperial period to the thinly veiled attempt to move into resource-rich Siberia and the Far East during the Allied "intervention" on the part of Anglo-Americans along with Canada, as well as France, China, and Japan in 1918, Nazi Germany's concept of Lebensraum, Americans' so-called "containment" policy during the Cold War, and the ongoing encirclement of Russia in the post-Soviet space, for instance, in Central Asia. These seemingly unrelated events can be explained by the general AngloAmerican geopolitical trajectory, surpassing ideology, from such theorists as Alfred Mahan at the end of the 19th century to Zbigniew Brzezinski at the end of the 20th. Terminological fluctuations notwithstanding, the general thrust of this strategy is the control of the Heartland, to use Halford Mackinder's name for Russian-ruled Eurasia, in order to gain access to the majority of the world's natural resources 
(Mackinder 1904: 421-437). Thus, having a large and more evenly distributed population size can be seen as a matter of national survival for the Russians.

In terms of ideology, after the Bolshevik Revolution, the Soviet government exhibited considerable interest in natalist thinking, although its specific treatment changed. Much like the natalist concerns in the modern states of the West in the interwar period, the USSR sought to manage its citizens to an unprecedented extent, ranging from setting an adequate level of education, culture, and taste to dictating attitudes toward their bodies, including the questions of hygiene and reproduction.

At first, in the 1920s, the Bolsheviks attempted to adhere to classic Marxism. In the arena of familial relations, this meant getting rid of patriarchal gender roles, legalizing abortion, and making divorce procedures simpler, among others. Certain radical figures, such as Aleksandra Kollontai, viewed the family institution and traditional Christian morality itself as remnants of the bourgeois past that had to be discarded, with the worker-state gaining a prominent role in raising children communally. The state did become more involved: the earliest Soviet poster advertising targeting social matters depicted orphanages featuring Classical architecture, which stated, "Children are the future of Soviet Russia"; others promoted the link between the health of the mother and her baby through government-issued healthcare (Snopkov et al 2006).

In the 1930s, however, the egalitarian measures from the previous decade were replaced by top-down "neo-traditionalism," as Western historians refer to it. Here, the state acted as the civiliser, including the reintroduction of ethnic heroes and classics in the arts and education, in light of the dramatically increased literacy level for which it was responsible; it also made vast improvements in the area of hygiene, fighting diseases, and infant mortality. For the family, this meant a return to somewhat patriarchal family values (but not in terms of pre-revolutionary property rights of the patriarchs or stay-at-home bourgeois housewives), sobriety, as well as natalist propaganda coupled with a ban on abortion, difficult-to-obtain divorces, and mockery of irresponsible husbands. ${ }^{6}$ This change was especially noticeable in visual culture. 1920s-early 1930s imagery depicted women in a rather gender-neutral manner. By contrast, by the mid-to-late 1930s, the emphasis on femininity re-entered social advertising (Hoffmann 2003). Furthermore, whereas this subject is beyond the scope of this paper, it is worth pointing out that other countries in the Soviet Bloc, such as Romania, exhibited certain comparable elements of state-imposed neo-traditionalism, such as restrictive abortions (Soare 2013: 59-78).

In part, the state's initiatives were a practical way to address the drop in fertility, creating a population crisis in the 1930s, which greatly concerned Soviet demographers. The crisis was caused by a number of factors, including the 193233 famine and the elimination of female unemployment, as a result of industrialisation and the collectivisation drive in agriculture. With women entering the workforce in such a radical manner in a short time period, the government took over the role of child care, starting as early as nursery schools (pre-kindergarten) around the tender age of two (Hoffmann 2003). Along with successes in the area of health and medicine, specifically infant-mortality reduction, the availability of such early childhood education facilities comprised the most significant solutions. Whereas we obviously cannot argue for the presence of a direct, causal link between this kind of social advertising and fertility, it does reflect traditional cultural mores at large.

\footnotetext{
${ }^{6}$ It is important to note that the USSR, like the Russian Empire before it and the Russian Federation afterward, was a multiethnic entity. Cultural specifics notwithstanding, non-Slavic regions, such as the traditionally Muslim-dominated areas in northern Caucasus or Central Asian republics, could be described as exhibiting an even greater degree of societal traditionalism.
} 
The next decade saw the establishment of the heroic mother (literally, "motherheroine") medal (1944) for women with 10 or more living children (naturally born or adopted), as well as two other lesser medals for similar achievements; the lowest award, the medal of motherhood, commemorated those with five or six children. This type of recognition symbolised one of the ways in which the Soviet government chose to combat the massive loss of life (24-26 million) during the course of WWII. After the war, the ratio of men to women was rather skewed, which caused additional problems. At this time, the state increased financial help to women who were pregnant or raising children, in general. Natalist propaganda intensified, creating or, at least, emphasizing the atmosphere of communal support. Poster advertising featured images of wholesome, but serious mothers surrounded by numerous children of all ages, including teenagers already serving in the Soviet armed forces. Others promoted orphan adoptions to mitigate the effects of war. ${ }^{7}$ The latter was a unifying experience for USSR's citizens, which approached the need to rebuild on a national basis as a common goal. For instance, at the end of the war, approximately $41 \%$ of orphaned children was adopted or in foster care. ${ }^{8}$

Figure 1. Total fertility rate, $1950-2011$

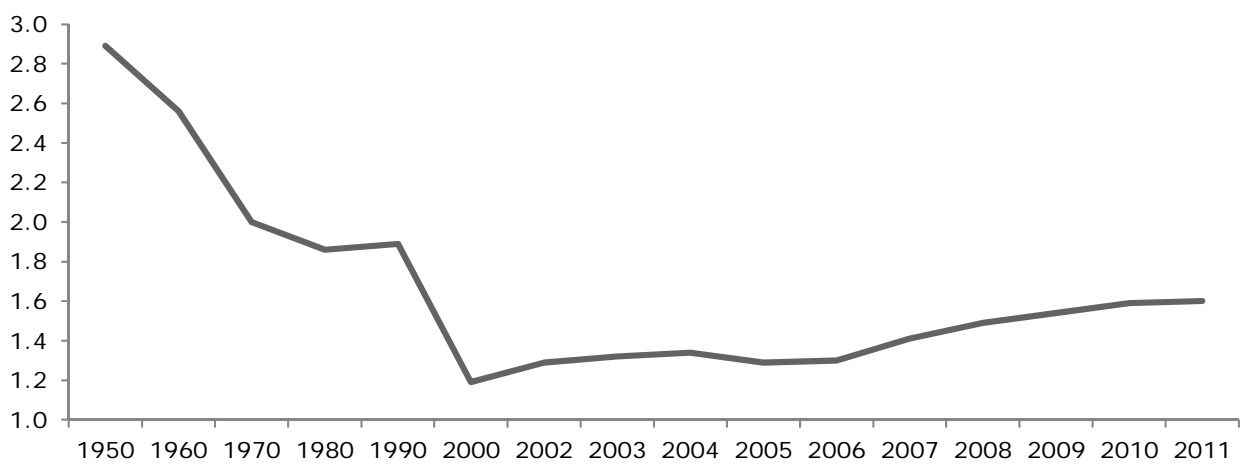

Data source: Institute of Demography at the National Research University 'Higher School of Economics', demoscope.ru.

Natalist social advertising continued throughout the majority of the Soviet period. Many examples targeted proper child care, in which the government played an active role, while the mother was at work, on the way to raising the new generation of well-educated, cultured, responsible, and healthy Soviet citizens. Abortion was legalised once again after Stalin's death (1953), as part of the general Khrushchev era liberalisation. Somewhat lower birth rates in the 1970s have, in part, been explained by the rise in the standard of living and related embourgoisement of the Brezhnev period. Soviet authorities provided reasonable time for maternity leave, maintaining salary and employment, as well as free post-secondary education. ${ }^{9}$ This meant that there was little conflict, at least in theory, between having several children and being able to provide for them.

\footnotetext{
7 See poster selection "Materinstvo v illiustratsiiakh," Materinstvo.ru (consulted 10 March 2013): materinstvo.ru/art/6214/; "Gosudarstvennye nagrady za materinstvo," RIA Novosti (consulted 10 March 2013): http://ria.ru/society/20090708/176642182.html.

8 "Istoriia usynovleniia v Rossii," Usynovlenie.ru (consulted 7 July 2013): http://www.usynovite.ru/experience/history/chapter1/.

9112 total calendar days before and after birth, maintaining salary and employment were introduced as early as 1917 , with the possibility to extend the leave (maintaining employment without maintaining full salary) up until the point when the child reaches 1 year. Additional measures were taken for women with multiple children ("Otpusk po beremennosti i rodam," Bolshaia Sovetskaia Entsiklopediia (Moscow: Sovetskaia entsiklopediia, 1969-1978)); see same at http://demography.academic.ru/2158/ОТПУСК_ПО_БЕРЕМЕННОСТИ_И_РОДАМ.
} 


\section{Natalism and Modernity in Scholarship}

Before moving onto contemporary natalist initiatives in the Russian Federation, it is worth having a brief look at Western historiography about the subject of "neotraditionalism" in the USSR, some of which was already used above. It is also important to consider the limitations of current Western scholarship linked to its own assumptions analyzing foreign subjects from a liberal (and now, post-liberal) perspective through the prism of the individual and the seemingly ever expanding "human rights" at the expense of authentic folkic communities. The earliest texts about 1930s USSR provided a rather straightforward ideological critique, arguing that the Stalinist regime backtracked on the egalitarian achievements of the Bolshevik coup d'état, such as women's rights. These texts can be traced to Leon Trotsky's Revolution Betrayed (1937), in which the exiled politician used Marxist analysis in order to highlight the conservative turn within the Soviet Revolution with the rise of Stalin. This strict ideological reading made him describe 1930s "neotraditionalist" programme as a general embourgoisement of the Soviet society, including patriarchal family structure and the emphasis on having several children (Trotsky 1937; Timasheff 1946; Dunham 1976).

In contrast to this analysis from a strictly Marxist ideological perspective, in the last 20 years or so, the modernity paradigm has become quite prominent in historical circles, bridging the gap between the different ideologies of the 20th century and drawing from different scholarly publications, including the work of Michel Foucault and James Scott's idea of modern population management, as mentioned above (Foucault 1975; Scott 1998). Born during the Enlightenment era, modernity spread throughout Europe, Russia, and beyond taking on culturally specific forms and thus resulting in an entire spectrum of "modernities." Its three main ideologies of the 20th century, liberalism, communism, and fascism, can also be described as three political theories. Each theory had a different historical subject: the individual in liberalism, class in communism, and the state or race in fascism, affecting the specifics of political expression. These ideologies challenged each other as the best representation of modernity, and liberalism ultimately triumphed. ${ }^{10}$ At the same time, they all shared several fundamental similarities, such as secularism, rationalism, materialism, economic determinism, and the belief in unidirectional, infinite progress as part of its unequivocal trust in science. In fact, the latter notion of continuous progress, not cycles of growth and decline, was conceived as the main trajectory of social and cultural development and the principal driving force in history (Dugin 2009).

Scholars of Russian history in the West have used the modernity spectrum to examine the issue of natalism and beyond, arguing that liberal, communist, and fascist states were all concerned with the bodies of their subjects, including, but not limited to: birth rates, health and hygiene, education as a form of social engineering, population replenishment after war; taxation levels (hidden or otherwise) as being linked to workforce size and social services of the Western welfare state or industry, agriculture, and the military in the historically socialist states; subject treatment on a largely ideological level, such as promoting or discouraging abortion as an issue of women's civil rights or traditional family values, and even aesthetics as they pertained to the question of race in Nazism and that of class in communism. This type of reading acknowledges cultural variation, but prefers the comparative framework of the generalised modernity paradigm.

Western historians especially gravitated toward what they saw as the most "natural" comparison between Nazi Germany and Stalinist USSR as the two most

\footnotetext{
10 The triumph of liberalism (for the sake of convenience, in 1991 with the Soviet collapse) as the most accurate representation of modernity also coincides with the beginning of postmodernity.
} 
extreme cases of modern population management (Hoffmann 2003). However, other studies demonstrated that this phenomenon was not limited to what these historians defined as "authoritarianism" (previously, "totalitarianism"). For instance, Mary Louise Roberts examined the natalist drive in France in the wake of the First World War and its massive loss of life, including suppressing contraception, linking it to Vichy regime era conservative gender relations (Roberts 2003: 91-101). Others analysed the authoritarian streak within nominally liberal regimes, as in the case of Gordon Chang's study of the Japanese internment camps in the United States during WWII (Chang 2003: 189-204).

Depicting the natalist drive in the West and Russia as one of the many population management techniques used by a powerful and intrusive state is not inaccurate, but provides only one piece of the puzzle. It certainly does not fully explain the support of the modern state on the part of the masses. For instance, what was the relationship between the Soviet government and nearly half a million women i.e., the total number of those awarded the heroic mother medal - who were motivated to have more than ten children, each? ${ }^{11}$ Western historians have realised the sheer complexity of this question when they linked it to the subject of resistance - that of individuals against the state. One of the difficulties here is rooted in divergent views of what comprises resistance, active and passive, and how to explain the support of a powerful state outside of various types of coercion (Viola 2002). ${ }^{12}$ A recent study by the Carnegie Endowment Fund concluded that contemporary Russians are "confused" because Stalin's popularity has grown among them, which does not fit into this think tank's liberal world view. ${ }^{13}$ The latter is part of a greater trend, often ignoring cultural diversity and specificity and measuring non-Western societies by liberal standards as mentioned above. There has to be something else that could adequately explain the relationship between the modern state, the supportive masses (exceptions notwithstanding), and the institution of "neo-traditionalism," which stood in seeming contradiction to the early years of the Soviet regime, when it attempted to adhere to Marxist dogma as closely as possible.

Recently, Russian philosopher Alexander Dugin attempted to explain that very "something." Admittedly, he ventured beyond the subject of history and used Gilbert Durand's two-tier method - the sociology of the imaginary, which synthesises the work of Carl Jung on the collective unconscious and that of David Émile Durkheim on the collective consciousness. This sociological research area refers to the sum total of overt cultural features as the logos, whereas mythos represents the symbolic and archaic undercurrents pushed into the unconscious in the rationalist, secularist, science-focused modern period. Ideally, there should be a strong connection between the logos and mythos, and the former should be an expression of the latter. The sociology of the imaginary has existed for a number of decades, but is a rather new direction for examining one's own history for Russian scholars. Its primary usefulness lies in its ability to supplement the aforementioned historic models (Dugin 2010).

In fact, Dugin asserts that the last several hundred years of Russian history, by and large, comprised the imposition or borrowing of a foreign Western European logos - and the transition from one such logos to another. The latter can be contrasted

\footnotetext{
${ }^{11}$ Between 1944-1991, according to "Presidium of the Supreme Soviet of the USSR adopted the first decree 'On awarding the honorary title of 'Mother Hero' to mothers of many children'," President's Library (consulted 10 March 2013): http://www.prlib.ru/en-us/history/Pages/ltem.aspx?itemid=296. It would be too simplistic to reduce these numbers to the lack of birth control.

${ }^{12}$ The question of resistance in the USSR is beyond the scope of this paper.

${ }^{13}$ De Waal, Thomas et al (2013) "The Stalin Puzzle: Deciphering Post-Soviet Public Opinion," The Carnegie Endowment Fund for International Peace (consulted 1 March 2013): http://www.carnegieendowment.org/2013/03/01/stalin-puzzle-deciphering-post-soviet-public-opinion/.
} 
with the fixed unconscious level of Russian culture, including myths, symbols, and dreams. Under the influence of the rationalist Enlightenment paradigm, there has been a tendency to suppress one's own myths (whether in the case of crushing the folk ways by the Europeanizing policies on the part of Peter the Great or the attempts to root out Orthodox Christianity during the early Bolshevik days), pushing them into the unconscious tier. This approach unifies and interprets the seemingly diverse processes and regime changes in Russian history in this broad time period under the umbrella of modernity, during which gradual secularisation occurred (Dugin 2010: 73).

The Russian version of the mystical nocturnal regime, in which the country's collective imagination functions, is associated with dreams of unity, absorption, and amalgamation, hence the appeal of the communal aspects of communism to Russians as a whole. ${ }^{14}$ As a result, Dugin asserts that the popular support for communism in the USSR was based on the marriage between the rational Marxist logos and the irrational Russian mythos, thereby establishing the Soviet system, which was oriented toward achieving this mystical unity in the future. In other words, many aspects of the Soviet system embodied the realisation of the people's collective unconscious. In fact, despite its rationalist, secularist roots in the Enlightenment period, the communist myth itself was a "unique and special archetype of the collective unconscious, a dream about an earthly paradise, in which the eschatological messianic cult opposed the official Christian religion," writes Dugin (Dugin 2010: 22, 60-65, 77-78). Ultimately, the myth of progress within modernity at large - leading toward this kind of a paradise - was, too, akin to irrational religious sentiment.

Let us apply Dugin's argument about mythic undercurrents under the apparently secular and rational communist regime to cover the subject of "neo-traditionalism." We can suggest that the partial return to certain traditional aspects of Russian culture, albeit within the framework of a modern state, was not merely a calculated population management method. The authorities themselves functioned as carriers of the strong folkic undercurrents in Russian culture, and, after the first dozen years under the strict Marxist - foreign - logos, the system morphed to include those aspects that were more naturally acceptable to the Russian society, such as those elements of "neo-traditionalism" described above. ${ }^{15}$

Thus, we can summarise the selective turn to traditionalism within the modern framework as follows. Revolutionary regimes that came into power through violence and instituted a radical social, political, and cultural programme cannot continue to function in the same extreme mode for an indefinite time period. Eventually (shortly), they arrive at normalisation, which considers the cultural particulars of its subject population as a kind of negotiation between them and the ruling elite. In the case of twentieth century Russia, an almost 10-year period comprising the naked violence of WWI, the Bolshevik Revolution, and the Civil War was accompanied (or followed) by a short period of turbulent social and cultural changes when the new Soviet state implemented a programme closely reflecting the foreign Marxist doctrine. By the mid-1920s, the state began to gradually introduce policies, haphazard at first, that were closer linked to the cultures comprising the USSR, resulting in "neo-traditionalism" by the mid-1930s. Roughly speaking, the case with the late 1980s-1990s was similar in terms of the attempts

\footnotetext{
${ }^{14}$ Dugin's assertion is based on several culturological factors, such as the predominance of powerful female characters in Russian fairy tales.

${ }^{15}$ There is even evidence for Dugin's assessment about the feminoid nature of Russian culture, with links to powerful female folk-tale characters, in 1930s social advertising. Despite the seeming reintroduction of patriarchal family life, the latter frequently depicted women as the centre and the glue of the family, whereas men were portrayed as irresponsible and prone to mistreating wives and children.
} 
to rapidly import another foreign liberal-capitalist system - with every imaginable negative consequence - followed by relative normalisation of the Putin era.

\section{Post-Soviet Russia}

With that in mind, let us have a look at the last 20 or so years of Russia's demographic policies and cultural perspectives, informed by an understanding that post-Soviet Russia has partially adopted the liberal-capitalist system. For instance, its current Constitution is based on Western European models, and the International Monetary Fund (IMF) puts pressure on the country to tighten its fiscal policy and increase the retirement age, as it does in Europe. Whereas liberalism takes root at the same Enlightenment source as communism, its focus on the individual is even less of a fit for communally oriented Russians.

Indeed, the tension between Russia's traditionalist (authentic or state-sponsored) perseverance in the face of Western liberal onslaught has even been implicitly mentioned in recent demographic studies about the country. Sergei Zakharov notes, for instance, that Russian completed-fertility levels of real cohorts differ little from Europe, yet Russia exhibits "neo-traditionalism" by displaying an early age for marriage and having the first child along with preferences for the woman's primary role as a mother (Zakharov 2008: 250). In addition, a more "clan-like" structure, in which grandparents and other relatives take an active role in child rearing - in contrast to the Western ideal of a "nuclear" family - is also quite prevalent. Ultimately, despite all these reasons, his argument is that Russia is heading the way of Europe if trends persist. But to what extent are these conclusions drawn from the constraints of their ideological framework?

After all, for demographers and policy makers, it is customary to discuss the latter in the context of familiar keywords, "development" and "progress" (here, explicitly comparing Russia to Western Europe). Such discussions are based on two major assumptions: that there is a single linear path of "development," and that this path ultimately ends up with Western Europe, perhaps with regional peculiarities that are trivial in the grand scheme of things; that progress necessarily has positive value, as its connotation itself implies. This assumes that each subsequent generation supersedes and improves upon the previous one: in other words, our ancestors are necessarily believed to be lesser versions of us because they did not reduce their existence to an economic-based, consumerist standard of living. Scholarly debate is normally framed in these particular terms without questioning the extent to which population management along with "development" in the direction of the contemporary West are even necessary; if any, criticism comes from ecologists concerned with climate change, population growth, and limited resources. Indeed, it is possible to view the Russian case in the opposite way: the persistence of "neo-traditionalism" as a way of resisting this kind of "development"; resilience in the face of modernity and postmodernity both under Soviet communism and partial liberalism.

In terms of fertility, there was noticeable decline toward the end of the Soviet period around the time of perestroika with deaths exceeding births shortly after the collapse of the USSR, according to Russia's statistical agency, Rosstat at gks.ru. In that decade, in addition to such detrimental factors as lowered life expectancy, abortion and divorce rates had been described as the highest in the world by the United Nations' web resource unstats.un.org. Considering the sheer turmoil of that period, ranging from questionable privatisation of public assets during the so-called "shock therapy" years to hyperinflation of the currency, causing the destruction of lifetime savings, the immediate assumption on the part of the government has been that the steady improvement of economic conditions would create an increase in birth rates. In 2006, Putin made Russian demographics one of the central issues of his presidency during his address to the nation. 
Since then, the solutions to Russia's dire population predictions have followed a two-tier approach involving straightforward financial rewards along with legal components as well as a socio-cultural initiative. The best known example of the former is the maternal-capital programme, which became operational in 2007. The latter involves various types of subsidies for women with more than one child, naturally born or adopted. This government aid package can only be spent on the child's education, pension investment, or the improvement of one's living conditions. Residential real estate in the largest cities in Russia (Moscow, St. Petersburg) remains near the top of the most expensive list in the world. This factor alone impedes certain urbanites from having more than one or two children. In terms of the judicial aspect, the state's attempts to combat relatively high mortality (as compared to Western Europe) among men - both due to disease and accidents - have involved increased punishment for reckless or inebriated driving, limits to the sale of beverages with high-alcohol content, and others.

Socio-cultural propaganda ranges from billboard advertising and holidays to television shows. There are parliamentary suggestions to reintroduce more modest versions of the "motherhood" medals. ${ }^{16}$ Even Western-modeled popular television dating shows such as Let's Get Married! (Davai Pozhenimsia!) systematically portray young female contestants who reaffirm their desire of marriage and children as their top priority, with careers being secondary, despite coming from urban environments. One particular cultural initiative is the All-Russian Day of Family, Love, and Faithfulness celebrated on 8 July. This is a typical example of a contemporary "neo-traditionalist" project by the state - established in 2008 - but with roots going back to older Russian culture, named after SS. Peter and Fevronia, medieval patron saints of marriage and love. And while the holiday was instituted by a secular government, its very focus points to another player in this matter, the Russian Orthodox Church. A traditional pillar of society, the Orthodox Church has experienced a true revival in the last 20 years, and has also been active in the demographic initiative from an overarching socio-cultural perspective. In addition to conventional measures such as the construction of thousands of new places of worship and the creation of Church-based orphanages, the Church has also embraced the new media, such as social networking, to spread its message of traditionalism. This institution sees the Russian population decline as part of the same trend affecting Europe (i.e., other historically Christian nations), naming the ideology of materialist, individualist liberalism as the culprit. Furthermore, in the last decade, there has been a certain sense of rapprochement between the Orthodox Church and other faiths, such as the indigenous Muslim clerics in Russia, who advocate similar goals for their respective regions.

Overall, the last 20 years, since the transition into a post-Soviet environment, demonstrate lower natural population gains than those of the Soviet period as a whole. Of course, we cannot discount the economic factors in their entirety. In general, Russians no longer have the multitude of social guarantees that they enjoyed as Soviet citizens. In addition to that, in the challenging decade of the 1990s, the loss of lifetime savings as a result of hyperinflation in the painful transition to a market-based economy made some Russians cautious, particularly in urban environments, in fear of being unable to provide for their families. As a result, they limit themselves with having one or two children.

The years of Putin's leadership, specifically, have coincided with a slight natural population increase as compared to the previous decade, although still below desirable levels. However, it is difficult to attribute the latter to government policies, as a cause and effect, rather than the overall stability of the first decade of the 21st century. Yet economic factors are only part of the equation, and it is the socio-

16 “Gosduma vernet zvanie 'Mat'-geroinia'," Izvestiia (consulted $10 \quad$ March 2013): http://izvestia.ru/news/545459. 
cultural dynamic that is likely to be of greater importance. Despite its selfproclaimed universalism, the contemporary individualist liberal-capitalist value system is specific to the West, and is even further removed from traditional Russia than hybridised Soviet socialism. The real solution to the country's demographic issues lies in the realisation of its authentic culture on political and social levels. To paraphrase Dugin, Russia's politics - social and otherwise - must embody the country's own logos, and the latter must be intimately connected to its mythos.

\section{References}

Antonov, Anatolii (2010) 'Demografiia v eru depopuliatsii,' Demograficheskie issledovaniia, $\quad$ vol. 11 (consulted 7 July 2013): http://demographia.ru/articles_N/index.html?idR=19\&idArt=78.

Chang, Gordon H. (2003). 'Social Darwinism vs. Social Engineering: the 'Education' of Japanese Americans during World War II.' In Landscaping the Human Garden: Twentieth-Century Population Management in a Comparative Framework, ed. Amir Weiner, 189-204. Stanford: Stanford University Press.

Dugin, Aleksandr (2009) Chetvertaia politicheskaia teoriia. St. Petersburg: Amfora.

Dugin, Aleksandr (2010) Logos i mifos. Moscow: Akademicheskii proekt.

Dunham, Vera (1976) In Stalin's Time: Middleclass Values in Soviet Fiction. Cambridge: Cambridge University Press.

Foucault, Michel (1975) Surveiller et punir. Paris: Gallimard.

Hoffmann, David (2003) Stalinist Values: The Cultural Norms of Soviet Modernity, 1917-1941. Ithaca: Cornell University Press.

Mackinder, Halford J. (1904) 'The Geographical Pivot of History,' The Geographical Journal 23(4): 421-437.

Martin, Terry (2000). 'Modernization or Neo-Traditionalism? Ascribed Nationality and Soviet Primordialism.' In Stalinism: New Directions, ed. Sheila Fitzpatrick, 348367. New York: Routledge.

Riis, Jacob (1890) How the Other Half Lives: Studies among the Tenements of New York. New York: Charles Scribner's Sons.

Roberts, Mary Louise (2003). 'The Dead and the Unborn.' In Landscaping the Human Garden: Twentieth-Century Population Management in a Comparative Framework, ed. Amir Weiner. Stanford: Stanford University Press, pp. 91-101.

Soare, Florin Stanica (2013) 'Ceausescu's Population Policy: a Moral or an Economic Choice between Compulsory and Voluntary Incentivised Motherhood?' European Journal of Government and Economics 2(1): 59-78.

Scott, James C. (1998) Seeing Like a State: How Certain Schemes to Improve the Human Condition Have Failed. New Haven: Yale University Press.

Snopkov, Aleksandr et al. (2006) Materinstvo i detstvo v russkom plakate. Moscow: Kontakt-kul'tura.

Timasheff, Nicholas (1946) The Great Retreat: The Growth and Decline of Communism in Russia. New York: E. P. Dutton \& Company.

Trotsky, Leon (1937) The Revolution Betrayed, Max Eastman (tr.). New York: Doubleday.

Viola, Lynne ed. (2002) Contending with Stalinism: Soviet Power \& Popular Resistance in the 1930s. Ithaca: Cornell University Press.

Zakharov, Sergei (2008) 'Russian Federation: From the First to Second Demographic Transition,' Demographic Research 19(24): 907-972. 